\title{
Penguatan Komunikasi Interpersonal Keluarga Migran di Kota Medan
}

\section{Strengthening Interpersonal Communication of Migrant Families in Medan City}

\author{
Syahrul Abidin* \\ Program Studi Ilmu Komunikasi, Fakultas Ilmu Sosial, \\ Universitas Islam Negeri Sumatera Utara, Indonesia
}

Diterima: Agustus 2019; Disetujui: Desember 2019; Dipublish: Desember 2019

\begin{abstract}
*Coresponding Email: syahrulabidin@uinsu.ac.id
Abstrak

Kebutuhan ekonomi dan tuntutan kesejahteraan menjadi pendorong dalam melakukan migrasi ke luar negeri sebagai pekerja migran yang kerap dapat menimbulkan permasalahan dalam keluarga. Sehingga perlu membangun sebuah komunikasi yang baik. Oleh sebab itu penting melakukan sebuah penguatan komunikasi interpersonal dalam keluarga guna meminimalisir keretakan rumah tangga (brokenhome). DeVito berpendapat bahwa komunikasi interpersonal adalah komunikasi yang terjadi diantara dua orang yang telah memiliki hubungan yang jelas, termasuk keluarga. Penulisan ini bertujuan untuk melihat penguatan komunikasi interpersonal keluarga migran Tenaga Kerja Indonesia yang ditinggalkan dalam membangun keharmonisan rumahtangga. Penguatan yang diberikan berupa penguatan verbal dengan menunjukkan sikap, respon keputusan dan persetujuan di dalam rumah tangga antara anak dan orangtua. Hasil penulisan ini menunjukkan bahwa penguatan komunikasi interpersonal yang dilakukan oleh keluarga migran yaitu meningkatkan perhatian, memberikan dorongan pendidikan anak, keterbukaan dan empati.
\end{abstract}

Kata Kunci: Komunikasi Interpersonal, Migran, Keluarga

\begin{abstract}
Economic needs and demands for welfare are the drivers in migrating abroad as migrant workers which can often cause problems in the family. So it is necessary to build a good communication. Therefore it is important to do a strengthening of interpersonal communication within the family in order to minimize household breakage (broken home). DeVito believes that interpersonal communication is communication that occurs between two people who already have a clear relationship, including family. This writing aims to see the strengthening of the interpersonal communication of migrant families of Indonesian Workers left behind in building harmony in the household. Strengthening is given in the form of verbal reinforcement by showing attitudes, decision responses and agreements in the household between children and parents. The results of this paper indicate that the strengthening of interpersonal communication carried out by migrant families is to increase attention, encourage children's education, lead to divergent ways of thinking or look for their own initiatives
\end{abstract}

Keywords: Interpersonal, Commnuication, Migrant, Family

How to Cite: Abidin, S. (2019). Penguatan Komunikasi Interpersonal Keluarga Migran di Kota Medan. Journal of Education, Humaniora and Social Sciences (JEHSS). 2 (2): 181-187.

\section{PENDAHULUAN}

Undang-Undang Kependudukan No. 52 Tahun 2019 mengamnatkan bahwa tujuan pembangunan keluarga bertujuan untuk meningkatkan kualitas keluarga agar timbul rasa aman tentram da nada harpan di masa depanyang lebih baik dalam mewujudkan ksejahteraan lahir dan batin. Namun demikian dalam mweujudkannya diperlukan adanya keseimbangan antara hak dan kewajiban di dalam rumah tangga tersebut. 象 $h$ ttp://mahesainstitute.web.id/ojs2/index.php/jehss 
Didalam praktiknya, masih banyak terdapat keluarga yang mengalami keretakan rumahtangga karena permasalahan ekonomi, sehingga harus memutuskan untuk bermigrasi ke luar negeri. Dengan tujuan untuk mencari penghasilan yang lebih baik yaitu sebagai Tenaga Kerja Indoensia (TKI). Menjadi seorang pekerja migran tentu memiliki resiko baik dari segi resiko sosial maupun domestik. Perkembangan tenaga kerja dari Indonesia yang bekerja di luar negeri dalam tiga periode terakhir menunjukkan, bahwa mereka yang bekerja itu cenderung menjadi buruh migran di sektor informal. Diperkirakan sampai tahun 2014 jumlah mereka mendekati 6.3 juta orang yang tersebar di 28 negara tujuan bekerja di tiga benua dunia, Asia pasifik (61.78\%), Timur Tengah dan Afrika (37.08\%), Eropa dan Amerika (1.14\%). Mereka ini dicatat berasal dari hampir seluruh pulau-pulau besar di Indonesia, seperti JawaMadura-Bali, NTB dan NTT, Sumatera, Kalimantan, dan Sulawesi. Bahkan, kawasankawasan perbatasan yang semula hanya menjadi tempat singgah atau transit mereka yang akan bekerja ke luar negeri, kini telah berkembang menjadi daerah pengirim tenaga kerja dari Indonesia ke luar negeri (Husmiati, 2015). Oleh sebab itu tidak jarang banyak anak yang ditelantarkan oleh orangtuanya karena alas an bermigrasi. Di Indonesia tercatat diperkirakan sebanyak 2-3 persen anak ditinggalkan oleh orang tuanya untuk bermigrasi ke luar negeri (Bryant, 2005 dalam Purwatiningsih 2016). Sementara itu, beberapa studi menunjukkan adanya dampak yang negatif yang ditimbulkan terhadap anak sebagai akibat dari migrasi yang dilakukan oleh orang tuanya. Meskipun memiliki dampak negatif, migrasi internasional merupakan fenomena yang terus meningkat aktivitasnya di Indonesia seiring dengan keterbatasan lapangan kerja yang tersedia di Indonesia.

Secara ekonomi, migrasi internasional memberikan sumbangan yang cukup besar dan tentu saja juga akan memberikan kesejahteraan pada rumah tangga. Namun migrasi internasional dalam bentuk pengiriman tenaga kerja migran juga memberikan dampak negatif maupun positif seperti yang telah banyak dilaporkan. Kemudian migrasi juga diikuti oleh beragam kebijakan yang melibatkan banyak pemangku kepentingan. Salah satu aspek yang ikut terdampak adalah kesehatan dan kesejahteraan anak dari tenaga kerja migran. Selain itu, perlu juga dilihat dampak yang ditimbulkan pada keluarga yang ditinggalkan maupun perubahan pada lingkungan sosial pada beberapa daerah yang menjadi kantungkantung tenaga kerja Indonesia. LSM Kalyanamitra mencatat 
Vol 2, No. 2, Desember 2019, DOI: https://doi.org/10.34007/jehss.v2i2.76

permasalahan sosial sebagai akibat bekerja keluar negeri adalah kemampuan keluarga mengolah ekonomi hasil bekerja di luar negeri, masalah keretakan keluarga, dan kenakalan anak-anak (www.kalyanamitra. or.id). Anak-anak yang ditinggal bermigrasi oleh orang tuanya sering kali mengalami permasalahan dalam pengasuhan anak, yang pada akhirnya juga akan berdampak terhadap psikologis anak. Di samping berdampak negatif terhadap kehidupan sosial anak, migrasi yang dilakukan oleh orang tua. Di sinilah pentingnya pendidikan dan pembudayaan dalam keluarga, sebagai keluarga inti dalam membentuk kepribadian anak (Suharyanto, 2015). Permasalahan keluarga migran seperti penjelasan di atas tidak hanya terjadi secara global di Indonesia namun terjadi juga di beberapa kota besar di Indonesia Seperti di Kota Medan.

Oleh sebab itu diperlukan suatu penguatan yang dapat mengokohkan dan menciptakan harmonisasi keluarga migran dengan pola penguatan komunikasi interpersonal. Komunikasi interpersonal yang dibangun melalui komunikasi verbal sejalan dengan pendapat (DeVito 1992, dalam Sapril 2011) berpendapat bahwa komunikasi interpersonal adalah komunikasi yang terjadi diantara dua orang yang telah memiliki hubungan yang jelas, yang terhubungkan dengan beberapa cara. Jadi komunikasi interpersonal misalnya komunikasi yang terjadi antara ibu dengan anak, atau bapak dan anak (Suharyanto, et.al, 2017). Tujuan penelitian ini adalah untuk mengetahui penguatan komunikasi interpesonal yang dilakukan oleh keluarga migran antara ibu sebagai pekerjan migran dengan anak yang ditinggalkan.

\section{METODE PENELITIAN}

Dalam penelitian ini, penulis menggunakan jenis penelitian kepustakaan (library research), yaitu serangkaian kegiatan yang berkenaan dengan metode pengumpulan data pustaka. Menurut (Moelong, 2008). Penelitian kepustakaan (library research) ialah penelitian yang mengunakan cara untuk mendapatkan data informasi dengan menempatkan fasilitas yang ada di perpus, seperti buku, majalah, dokumen, catatan data sekunder, data statistik atau penelitian kepustakaan murni yang terkait dengan obyek penelitian. Selanjutnya perlu dilakukan analisis deskriptif. Metode analisis deskriptif memberikan gambaran dan keterangan yang secara jelas, objektif, sistematis, analitis dan kritis mengenai penguatan komunikasi interpersonal keluarga migran. Langkah awal 
Syahrul Abidin, Penguatan Komunikasi Interpersonal Keluarga Migran di Kota Medan

yang ditempuh dengan mengumpulkan data-data yang dibutuhkan, kemudian dilakukan klasifikasi dan deskripsi.

\section{HASIL DAN PEMBAHASAN}

\section{Penguatan Komunikasi Interpersonal Keluarga Migran}

\section{Aspek Perhatian}

Sikap yang ditunjukkan seorang anak yang terpisah dengan orangtuanya anak tentu beragam. Paling banyak sikap yang ditunjukkan adalah rasa sedih. Dikarenakan karena rindu terhadap orang tuanya, tetapi banyak juga yang menyikapinya secara biasa saja. Secara umum, anak yang berpisah dengan orangtuanya untuk bermigrasi justru lebih banyak mengatakan sedih karena rindu. Demikian juga pada suami atau istri yang ditinggalkan oleh pekerja migran. Permasalahan yang mucul adalah bagaimana cara membangun komitmen diantara keluarga yang ditinggalkan dan yang meninggalkan. Dari hasil informasi yang didapatkan dari BNP2TKI 2012 khususnya migran asal Kota Medan sangat komitmen dengan keluarga yang ditinggalkan dalam menjaga keutuhan keluarga pekerja migran. Komunikasi berupa perhatian menjadi aspek penting di dalam menjaga keharmonisan keluarga. Terjaminnya komunikasi antara sumami istri dan anak dalam keluarga dapat menciptakan suasana saling memahmi dan saling bekerjasama dalam keluarga.

Pasangan suami istri yang menjadi TKI, terutama karena faktor ekonomi, memiliki hubungan yang kuat dengan pasangannya. Ketika tiba dan mulai bekerja di negara tempatnya bekerja, akan berusaha untuk melakukan komunikasi dengan keluarga atau pasangannya. Komunikasi itu dilakukan menggunakan telepon genggam dan media sosial. Untuk komunikasi, istri atau suami yang menjadi TKI itu yang akan berinisiatif. Intensitas komunikasi itu bisa sekali dalam sehari, atau dua kali dalam sepekan dengan masa telepon antara satu jam hingga dua jam. Untuk meluapkan rasa kangen itu, dalam komunikasi menggunakan videocall. Inisiatif telepon yang sering dilakukan oleh pasangan yang menjadi TKI, maka dalam komunikasi interpersonal itu dilakukan di saat istirahat dan pulang kerja. Melalui komunikasi interpersonal itu, komunikasi keseimbangan terbalik akan tercipta. Istri atau suami yang menjadi TKI, mempercayakan urusan rumah dan tanggung jawab sepenuhnya pada pasangannya (Napitupulu, 2017). Tinggal dengan jarak jauh menjadi masalah yang serius bagi pasangan suami istri. Untuk 
Vol 2, No. 2, Desember 2019, DOI: https://doi.org/10.34007/jehss.v2i2.76

menjaga keharmonisan dan keutuhan keluarga, pasangan suami istri dalam melakukan komunikasi saling menjaga perasaan dan keterbukaan. Disamoing itu juga TKI juga memperhatikan pendidikan anak meskipun hanya menanyakan kegiatan anak di sekolah maupun perkembangan nilai-nilai mereka. (Baihaqi, 2018).

\section{Memberikan Dorongan Pendidikan Anak,}

Pendidikan merupakan suatu faktor kebutuhan dasar untuk setiap manusia dalam upaya mencerdaskan kehidupan bangsa, karena melalui pendidikan peningkatan kesejahteraan rakyat dapat diwujudkan. Pendidikan memiliki peran penting dalam kehidupan berbangsa dan bernegara untuk menciptakan sumber daya manusia yang berkualitas. Penyebab kesejahteraan suatu negara, dengan mengisolasi dua faktor, yaitu; 1) pentingnya skala ekonomi; dan 2) pembentukan keahlian dan kualitas manusia. Faktor yang kedua inilah yang sampai saat ini telah menjadi isu utama tentang pentingnya pendidikan dalam meningkatkan pertumbuhan ekonomi. Remitan adalah salahsatu bentuk dorongan ekonomi dalam meningkatkan pendidikan anak keluarga migran Berdasarkan hasil penelitian remitan atau pengiriman uang TKI ke dalam negeri. Berdasarkan hasil penelitian (Laila, 2011) remitan atau pengiriman uang TKI ke dalam negeri pada tingkatan sangat tinggi yaitu sebanyak 9,4\%, tingkatan tinggi sebanyak 71,9\% dan cukup 18,8\%. Rata-rata jumlah uang yang dikirim TKI adalah 5-10 juta dengan periode waktu 6 bulan sekali. Uang remitan tersebut sebagian digunakan untuk pendidikan anak dan sebagian lagi ditabung ataupun untuk investasi. Bentuk pengiriman remitan tersebut dilakukan dengan pengiriman melalui pos atau wesel.

\section{Empati}

Peranan komunikasi keluarga sangat penting terhadap perkembangan sosial anak, tidak hanya terbatas pada situasi sosial ekonominya atau keutuhan struktur dan interaksinya saja di samping itu juga, keluarga memiliki peran yang sangat penting dalam upaya mengembangkan pribadi anak. Perawatan orang tua yang penuh kasih sayang dan pendidikan tentang nilai-nilai kehidupan, baik agama maupun sosial budaya yang diberikan merupakan faktor yang kondusif untuk mempersiapkan anak menjadi pribadi dan anggota masyarakat yang sehat. Komunikasi dalam keluarga terbentuk bila hubungan timbal balik selalu terjalin antara ayah, ibu dan anak". Dari uraian di atas dapat disimpulkan bahwa intensitas komunikasi keluarga adalah tingkat kedalaman dalam penyampaian pesan dari orang tua kepada anak, atau dari anak kepada orang tua 
yang di ikuti oleh kejujuran, kepercayaan, keterbukaan, penerimaan, dukungan, sehingga menimbulkan respon dalam bentuk perilaku sikap empati. Empati sangat diperlukan dalam membangun hubungan baik dalam masyarakat, teman sebaya siswa, dan terlebih lagi dalam keluarga. Sikap empati dapat mengajarkan bagaimana cara memahami lingkungan, teman sebaya dan dapat membantu ketika sebaya siswa sedang menghadapi masalah. Tanpa empati tidak bisa menyelami pikiran dan perasaan orang lain. Menurut (Depdikbud, 1995), empati berarti keadaan mental yang membuat seseorang merasa atau mengidentifikasi dirinya dalam keadaan perasaan atau pikiran yang sama dengan orang lain atau kelompok lain. Lebih gampangnya empati berarti mampu menempatkan diri seolah-olah menjadi seperti orang lain. Demikian juga halnya dengan sikap seseorang yang jauh dari keluarga diharapakan selalu memberikan empati kepada keluarga guna menjaga keharmonisan rumahtangga.

Dari ketiga komonen penguatan komunikasi interpersonal diatas dapat disimpulkan bahwa Penguatan komunikasi interpersonal keluarga migran adalah suatu komunikasi antara orang tua dengan anak yang sangat perlu dibangun secara harmonis dalam rangka membangun hubungan yang baik dalam keluarga (Taufik, 2012). Disamping itu sikap empati sebagai perubahan imajinasi seseorang ke dalam pikiran, perasaan, dan perilaku orang lain. Penguatan komunikasi dalam keluarga merupakan suatu bentuk komunikasi yang terjadi antar orang tua, antara orang tua dengan anak, dan antara anak dengan anak. Komunikasi yang efektif perlu dibangun dan dikembangkan dalam keluarga karena faktor konsistensi informasi, ketegasan, dan rasa saling percaya satu sama lain akan menumbuhkan sikap sosial yang baik. Komunikasi yang terjadi secara verbal dalam keluarga melibatkan semua unsur komunikasi baik pesan, kesan, maupun umpan balik. Dari keluarga migran mulai berkembangnya perilaku atau sikapnya terhadap orang lain termasuk sikap empati.

\section{SIMPULAN}

Dari penjelasan hasil penelitian dan pembahasan yang telah diuraikan diatas maka yang menjadi kesimpulan dalam penelitian ini adalah bahwa penguatan komunikasi interpersonal yang dilakukan oleh keluarga migran yaitu meningkatkan perhatian, memberikan dorongan pendidikan anak, keterbukaan dan empati. Ketiga aspek tersebut dapat menjadi sebuah pegangan bagi migran yang meninggalkan keluarganya, sehingga dapat meminimalisir terjadinya perceraian dan manjaga keharmonisan rumahtangga. 


\section{DAFTAR PUSTAKA}

Baihaqi, A (2018), Komunikasi Keluarga Buruh Migran Indonesia: Masalah dan Penyelesaian, Jurnal JIKE, Vol 1, No 2, Juni 2018

DeVito, J.A. (1992). The Interpersonal Communication Book. 6th ed. New York: Karper Collins.

Husmiati, dkk. (2015). Sosial Pekerja Migran Bermasalah Melalui Rumah Perlindungan Trauma Cente. Jakarta: P3KS Press.

Moeloeng, J.L. (2008) Metodologi Penelitian Kualitatif, Bandung: PT Remaja Rosdakarya

Napitupulu. M.A. Hasibuan, E.J. \& Hidayat, T.W. (2017). Persepsi Tenaga Kerja Indonesia Terhadap Gaya Komunikasi Instruktur dalam Memberikan Pembekalan Materi. PERSPEKTIF, 6 (1): 13-17.

Ngasinan, Kecamatan Weleri dan Kelurahan Ketapang, Kecamatan kota Kendal, Skripsi, Jurusan Geografi Fakultas Ilmu Sosial Universitas Negeri Semarang

Purwatiningsih, S (2016). Respons Anak-Anak Migran Terhadap Migrasi Internasional Di Perdesaan Ponorogo, Journal Populasi Volume 24 Nomor 1

Sapril, (2011). Komunikasi Interpersonal Pustakawan, Jurnal Iqra'. Volume 05 No.01

Suharyanto, A. (2015). Pendidikan dan Proses Pembudayaan dalam Keluarga, Jurnal Pendidikan Ilmu-Ilmu Sosial, 7 (2) (2015): 162-165.

Suharyanto, A. Matondang, A. Walhidayat, T. (2017). The Interpersonal Communication of the Chinese Ethnic Families in Cheng Beng Ceremony in Medan, Indonesia. IOSR Journal Of Humanities And Social Science (IOSR-JHSS), 22(12)Ver.4:38-44

Taufik. (2012). Empati Pendekatan Psikologi Sosial. Jakarta: Rajagrafindo

Tsani, (2011). Peran serta orang tua/ Wali Dalam Pendidikan Anak Keluarga Tki Kabupaten Kendal Di Desa

www.kalyanamitra. or.id 